LINO, VAS; BEZERRA NETO, F; LIMA, JSS; SANTOS, EC; NUNES, RLC; GUERRA, NM; LINO, FKKS; SÁ, JM; SILVA, JN. 2021. Beet-arugula intercropping under green manuring and planting density induce to agro-economic advantages. Horticultura Brasileira 39: 432-443. DOI: http://dx.doi. org/10.1590/s0102-0536-20210413

\title{
Beet-arugula intercropping under green manuring and planting density induce to agro-economic advantages
}

\author{
Vitor AS Lino ${ }^{1} \mathbb{D}$; Francisco Bezerra Neto ${ }^{1} \mathbb{D}$; Jailma SS Lima ${ }^{1} \mathbb{D}$; Elizangela C Santos ${ }^{1} \mathbb{D}$; Renato LC Nunes ${ }^{2} \mathbb{D}$; \\ Natan M Guerra ${ }^{1} \mathbb{D}$; Francisca Karla KS Lino ${ }^{1} \mathbb{D}$; Jolinda M Sá ${ }^{3 \mathbb{D}}$; Josimar N Silva ${ }^{1 \mathbb{D}}$
}

'Universidade Federal Rural do Semi-Árido (UFERSA), Mossoró-RN, Brasil; vabel55@gmail.com; bezerra@ufersa.edu.br; jailma@ufersa. edu.br; elizangelacabral@ufersa.edu.br; ntnguerra@ gmail.com; karlakellysilva@gmail.com; josimar2160@ hotmail.com; ${ }^{2}$ Instituto Federal do Ceará (IFCE), Limoeiro do Norte-CE, Brasil, renatoleandro.ce@hotmail.com; ${ }^{3}$ Universidade Federal de Campina Grande (UFCG), Pombal-PB, Brasil; jolindamercia@gmail.com

\begin{abstract}
One of the biggest challenges in the intercropping system of two crops is to obtain the optimal dose of green manure and the adequate population density of the crops. So, the objective of this work was to evaluate the performance of beet and arugula intercropping, influenced by green manuring with Merremia aegyptia and Calotropis procera and arugula population densities in two cultivation years, in semi-arid environment. The experimental design used was in randomized complete blocks, with the treatments arranged in a $4 \mathrm{x}$ 4 factorial scheme, with 4 repetitions. The first factor of this scheme consisted of equitable amounts of $M$. aegyptia and $C$. procera biomass $\left(20,35,50\right.$ and $65 \mathrm{t} \mathrm{ha}^{-1}$ on a dry basis) and the second factor, by arugula population densities $(40,60,80$ and $100 \%$ of the recommended density for single cropping, corresponding to 400,600 , 800 and 1,000 thousand arugula plants $\mathrm{ha}^{-1}$ ). The production and its components were evaluated on beet and arugula. In addition to these characteristics, the following agro-economic indicators were also determined for each treatment: system productivity index (SPI), land equivalent coefficient (LEC) and monetary equivalent ratio (MER). The greatest agro-economic advantages of the beet with arugula intercropping were achieved with a system productivity index (SPI) of $53.47 \mathrm{tha}^{-1}$, land equivalent coefficient (LEC) of 0.84 and a monetary equivalent ratio (MER) of 1.56, respectively, combining $65 \mathrm{t} \mathrm{ha}^{-1}$ of $M$. aegyptia and C. procera biomass with the arugula population density of 1,000 thousand plants ha ${ }^{-1}$. The maximum optimized commercial productivity of beetroots in the system intercropped with arugula was $23.20 \mathrm{t} \mathrm{ha}^{-1}$ using $65 \mathrm{t} \mathrm{ha}^{-1}$ of M. aegyptia and C. procera and in the arugula population density of 1,000 thousand plants $\mathrm{ha}^{-1}$, while the maximum arugula productivity intercropped with beet was 9.65 $\mathrm{t} \mathrm{ha}^{-1}$, in the same combination of green manures amount and arugula population density.
\end{abstract}

Keywords: Beta vulgaris, Eruca sativa, Merremia aegyptia, Calotropis procera, mixed-cropping economic returns.

\section{RESUMO}

Consórcio de beterraba e rúcula sob adubação verde e densidade de plantio levam a vantagens agroeconômicas

Um dos maiores desafios no sistema consorciado de duas culturas é obter a dose ótima de adubos verdes e a densidade populacional adequada das culturas. Assim, o objetivo deste trabalho foi avaliar o desempenho da beterraba e rúcula em consórcio quando influenciadas pela adubação verde com Merremia aegyptia e Calotropis procera e densidades populacionais de rúcula, em dois anos de cultivo, em ambiente semiárido. $\mathrm{O}$ delineamento experimental utilizado foi em blocos completos casualizados, com os tratamentos arranjados em esquema fatorial $4 \times 4$, com 4 repetições. O primeiro fator desse esquema foi constituído de quantidades equitativas de misturas de biomassa de $M$. aegyptia e C. procera $\left(20,35,50\right.$ e $65 \mathrm{t} \mathrm{ha}^{-1}$ em base seca) e, o segundo fator, de densidades populacionais de rúcula (40, 60,80 e $100 \%$ da densidade recomendada para o cultivo solteiro, correspondendo a 400, 600, 800 e 1.000 mil plantas de rúcula ha ${ }^{-1}$ ). A produção e seus componentes foram avaliados na beterraba e na rúcula. Além dessas características, também foram determinados os seguintes indicadores agroeconômicos para cada tratamento: índice de produtividade do sistema (SPI), coeficiente equivalente de terra (LEC) e razão equivalente monetária (MER). As maiores vantagens agroeconômicas do consórcio de beterraba com rúcula foram alcançadas com um índice de produtividade do sistema (SPI) de $53.47 \mathrm{t} \mathrm{ha}^{-1}$, coeficiente equivalente da terra (LEC) de 0.84 e uma razão equivalente monetária (MER) de 1.56, respectivamente, na combinação de $65 \mathrm{t} \mathrm{ha}^{-1}$ de biomassa de $M$. aegyptia e $C$. procera com a densidade populacional de 1 milhão de plantas de rúcula por hectare. A produtividade comercial máxima otimizada de raízes de beterraba no sistema consorciado com rúcula foi de 23,20 $\mathrm{t} \mathrm{ha}^{-1}$ na quantidade de $65 \mathrm{t} \mathrm{ha}^{-1}$ de $M$. aegyptia e $C$. procera e na densidade populacional de 1 milhão de plantas de rúcula por hectare, enquanto a máxima produtividade de rúcula, em consórcio com beterraba, foi de 9,65 tha ${ }^{-1}$, na mesma combinação de quantidade de adubos verdes e densidade populacional de rúcula.

Palavras-chave: Beta vulgaris, Eruca sativa, Merremia aegyptia, Calotropis procera, retornos econômicos em culturas consorciadas. 
$\mathrm{B}$ eet and arugula are vegetables whose cultivation is growing in the semi-arid region of northeastern Brazil, as they are economically viable crops and offer healthy products to consumers, although their consumption is still low (Andrade Filho et al., 2020). In view of the population's search for healthy food, the demand for these vegetables is increasing and so their production systems need scientific and technological information.

The production systems with these vegetables in the semi-arid region have been through intercropping cultures, where the cultures are able to coexist together efficiently, in order to increase the aggregated production per unit of input, guarantee against breaking crop and market fluctuations, meet food preference and/or cultural demands, and increase producer's income (Gebru, 2015). This cultivation practice allows optimizing the use of environmental resources, such as nutrients, water and solar radiation, since the plant species have different growth cycles.

The cultivation of a tuberous root with a broadleaf vegetable in an intercropped system requires large amounts of nutrients, mainly due to its short period of development and growth (Silva et al., 2018). One of the ways to meet this requirement is through the use of green manuring with mixtures of biomass from spontaneous species in the Caatinga biome, such as Merremia aegyptia and Calotropis procera. These species, according to Linhares et al. (2012), contain a good supply of nutrients, suitable biomass production and low $\mathrm{C} / \mathrm{N}$ ratio, which provides the decomposition and faster release of nutrients for plants.

Moraes et al. (2019), using $C$. procera as a fertilization source in the cowpea intercropped with beet, obtained greater productive efficiency of the intercropped system, incorporating 65 t ha ${ }^{-1}$ biomass of this green manure into the soil. In turn, Silva et al. (2018), manuring the intercropping of beet and lettuce with $M$. aegyptia, obtained the highest agro-economic performance of the intercropping of these vegetables with the incorporation of approximately $35.30 \mathrm{t} \mathrm{ha}^{-1}$ of this green manure biomass.

Another production factor that affects intercropped vegetable production systems is the population density of component crops, as it induces a series of changes in the plant growth and development and needs to be known in greater detail to determine yield and production efficiency of the system (Bezerra Neto et al., 2005).

It is known that the increase in population density can influence the quality of tuberous roots, as the carrot increasing the number of fine roots and reducing the average root size, due to the greater competition for water and nutrients imposed on plants. The population increase also interferes in the aerial part of the plants, increasing the production of branches and decreasing their diameter (Oliveira et al., 2017).

Batista et al. (2016), studying the intercropping of carrot with arugula manured with $M$. aegyptia in different population densities, obtained greater productive and economic efficiency of the intercropped system when using the carrot population density of 200 thousand plants $\mathrm{ha}^{-1}$ and of 1,000 thousand arugula plants ha ${ }^{-1}$.

Aiming to provide greater subsidies for the development of technologies for the production of beet tuberous vegetable intercropped with the arugula leafy crop, this work evaluated the performance of beet and arugula, influenced by green manuring of $M$. aegyptia and C. procera and arugula population densities in two cropping years in a semi-arid environment.

\section{MATERIAL AND METHODS}

Two field experiments were conducted at the Experimental Farm 'Rafael Fernandes' of the Universidade Federal Rural do Semi-Árido (UFERSA), located in the district of Lagoinha, $20 \mathrm{~km}$ from the municipality of Mossoró, RN

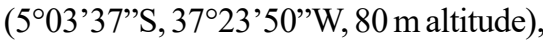
being the first experiment from October to December 2018 and the second from September to November 2019. The climate of the region, according to the Köppen's classification, is 'BShw', dry and very hot, with two seasons: a dry season, which usually occurs from June to January and a rainy season, from February to May (Alvares et al., 2014). During the experimental periods, the recorded average values for minimum, mean and maximum temperatures, relative humidity and precipitation for the cropping years 2018 and 2019 were respectively: $23.68,28.44$ and $33.2^{\circ} \mathrm{C}$; $22.61,27.79$ and $32.98^{\circ} \mathrm{C} ; 66.74$ and $67.39 \%$, and 0.4 and $4.4 \mathrm{~mm}$ (INMET, 2019).

The soils in the experimental areas were classified as typical Argisol Red Yellow Dystrophic with a sandy-loam texture (Santos et al., 2018). In each experimental area, simple soil samples of the $0-20 \mathrm{~cm}$ surface layer were collected, homogenized to obtain a composite sample, representative of the area, whose results in cultivation in 2018 were: $\mathrm{pH}($ water $)=8.10 ; \mathrm{EC}=0.24$ $\mathrm{dS} \mathrm{m}{ }^{-1}$; O.M. $=4.97 \mathrm{~g} \mathrm{~kg}^{-1} ; \mathrm{N}=0.35 \mathrm{~g}$ $\mathrm{kg}^{-1} ; \mathrm{P}=22.80 \mathrm{mg} \mathrm{dm}^{-3} ; \mathrm{K}=64.70 \mathrm{mg}$ $\mathrm{dm}^{-3} ; \mathrm{Ca}=3.28 \mathrm{cmol} \mathrm{dm}^{-3} ; \mathrm{Mg}=0.78$ $\mathrm{cmol}_{\mathrm{c}} \mathrm{dm}^{-3} ; \mathrm{Na}=32.70 \mathrm{mg} \mathrm{dm}-3 \mathrm{Cu}^{-3}$ $0.10 \mathrm{mg} \mathrm{dm}^{-3} ; \mathrm{Fe}=1.91 \mathrm{mg} \mathrm{dm}^{-3} ; \mathrm{Mn}=$ $11.67 \mathrm{mg} \mathrm{dm}^{-3} ; \mathrm{Zn}=2.63 \mathrm{mg} \mathrm{dm}^{-3}$. In 2019 cultivation the results were: $\mathrm{pH}$ (water) $=7.10 ; \mathrm{EC}=0.10 \mathrm{dS} \mathrm{m}^{-1}$; O.M. $=$ $5.27 \mathrm{~g} \mathrm{~kg}^{-1} ; \mathrm{N}=0.28 \mathrm{~g} \mathrm{~kg}^{-1} ; \mathrm{P}=22.00$ $\mathrm{mg} \mathrm{dm}{ }^{-3} ; \mathrm{K}=69.47 \mathrm{mg} \mathrm{dm}^{-3} ; \mathrm{Ca}=2.70$ $\mathrm{cmol}_{\mathrm{c}} \mathrm{dm}^{-3} ; \mathrm{Mg}=0.50 \mathrm{cmol}_{\mathrm{c}} \mathrm{dm}^{-3} ; \mathrm{Na}=$ $26.70 \mathrm{mg} \mathrm{dm}^{-3} ; \mathrm{Cu}=0.24 \mathrm{mg} \mathrm{dm}^{-3} ; \mathrm{Fe}=$ $2.71 \mathrm{mg} \mathrm{dm}^{-3} ; \mathrm{Mn}=12.17 \mathrm{mg} \mathrm{dm}^{-3} ; \mathrm{Zn}=$ $5.27 \mathrm{mg} \mathrm{dm}^{-3}$.

The experimental design used was in complete randomized blocks, with the treatments arranged in a $4 \times 4$ factorial scheme, with 4 replicates, where the first factor consisted of equitable amounts of $M$. aegyptia and $C$. procera biomass mixtures $\left(20,35,50\right.$ and $65 \mathrm{tha}^{-1}$ on a dry basis) and, the second factor were arugula population densities $(40,60,80$ and $100 \%$ of the recommended density for single cropping, corresponding to $400,600,800$ and 1,000 thousand arugula plants). The recommended population densities for single croppings of beet and arugula in the region are 500 and 1,000 thousand plants ha $^{-1}$, respectively (Silva et al., 2011; Oliveira et al., 2015a). In each block, beet and arugula single plots were planted with biomass equitable amounts of $M$. aegyptia and $C$. procera optimized by 
the research to obtain the agronomic and economic indexes of the intercropped systems. The spacings used in each population are described in Table 1.

The intercropping of beet with arugula was established in alternating strips in the proportion of $50 \%$ of the area cultivated with beet and $50 \%$ of the area cultivated with arugula. In each experimental plot, the alternating strips consisted of four rows, flanked by two rows of arugula on one side and two rows of beet on the other side, used as borders. The total area of each plot was $2.88 \mathrm{~m}^{2}(2.40 \times 1.20 \mathrm{~m})$, with a useful area of $1.60 \mathrm{~m}^{2}(1.60 \times 1.00 \mathrm{~m})$, where this area consisted of two central strips of plants, excluding the two final plants of each row used as borders. In this cultivation system, the same beet population density of the single crop was used.

Single vegetable crops were established in a total area of $1.44 \mathrm{~m}^{2}$ $(1.20 \times 1.20 \mathrm{~m})$, with a useful area of $0.80 \mathrm{~m}^{2}(0.80 \times 1.00 \mathrm{~m})$, where beet was planted in the spacing $0.20 \times 0.10$ $\mathrm{m}$ and the arugula in the spacing 0.20 $\mathrm{x} 0.05 \mathrm{~m}$. Plants were harvested in the 4 central cultivation lines, excluding the sidelines, as well as the first and last plants of each cultivation line, considered borders.

The soil preparation consisted of plowing and harrowing, followed by raising the beds with the aid of a soil grower. After soil preparation, a preplanting solarization was carried out for 30 days with $30 \mu \mathrm{m}$ transparent plastic (Vulca Brilho Bril Fles) following the methodology recommended by Silva et al. (2006), in order to reduce the population of phytopathogenic organisms present in the soil, which could potentially harm crop productivity.

The materials used as green manures were hairy woodrose (Merremia aegyptia) and roostertree (Calotropis procera), collected from native vegetation in several locations in the rural area of the municipality of Mossoró, RN, before the beginning of flowering. After collecting the green manures, these were crushed into two to three centimeters fragments. These were dehydrated at room temperature until reaching $10 \%$ moisture content and then, subjected to laboratory analysis, whose chemical compositions were, in 2018: $\mathrm{N}=11.40 \mathrm{~g} \mathrm{~kg}^{-1} ; \mathrm{P}=2.36 \mathrm{~g} \mathrm{~kg}^{-1}$; $\mathrm{K}=2.20 \mathrm{~g} \mathrm{~kg}^{-1} ; \mathrm{Mg}=9.75 \mathrm{~g} \mathrm{~kg}^{-1}$ and $\mathrm{Ca}=$ $8.30 \mathrm{~g} \mathrm{~kg}^{-1}$, for hairy woodrose and $\mathrm{N}=$ $18.40 \mathrm{~g} \mathrm{~kg}^{-1} ; \mathrm{P}=3.14 \mathrm{~g} \mathrm{~kg}^{-1} ; \mathrm{K}=4.50 \mathrm{~g}$ $\mathrm{kg}^{-1} ; \mathrm{Mg}=13.35 \mathrm{~g} \mathrm{~kg}^{-1}$ and $\mathrm{Ca}=16.30 \mathrm{~g}$ $\mathrm{kg}^{-1}$, for roostertree. In 2019: $\mathrm{N}=16.60$ $\mathrm{g} \mathrm{kg}^{-1} ; \mathrm{P}=2.79 \mathrm{~g} \mathrm{~kg}^{-1} ; \mathrm{K}=47.80 \mathrm{~g} \mathrm{~kg}^{-1}$; $\mathrm{Mg}=7.07 \mathrm{~g} \mathrm{~kg}^{-1}$ and $\mathrm{Ca}=19.35 \mathrm{~g} \mathrm{~kg}^{-1}$, for hairy woodrose and $\mathrm{N}=21.90 \mathrm{~g}$ $\mathrm{kg}^{-1} ; \mathrm{P}=1.92 \mathrm{~g} \mathrm{~kg}^{-1} ; \mathrm{K}=20.90 \mathrm{~g} \mathrm{~kg}^{-1}$; $\mathrm{Mg}=9.22 \mathrm{~g} \mathrm{~kg}^{-1}$ and $\mathrm{Ca}=17.00 \mathrm{~g} \mathrm{~kg}^{-1}$ for roostertree.

The cultivars of 'Early Wonder' beet and 'Cultivated' arugula were sown in October in the first cropping, and in November in the second arugula cropping of the year 2018 and in September in the first cultivation, and in October in the second arugula cropping in the year 2019, in holes approximately $3 \mathrm{~cm}$ deep, with three to four seeds per hole, and covered with commercial substrate. After thinning, two plants were left per hole for arugula and one plant per hole for beet in the intercropped system, and in single cropping only one plant per hole for both crops.

Irrigations were daily, using a micro sprinkler system, partitioned into two irrigations (morning and evening). The amount of supplied water was determined from the coefficient of the beet crop (average Kc: 0.83) (Oliveira Neto et al., 2011), with irrigation depth, when necessary, of approximately $8 \mathrm{~mm}$ day $^{-1}$. Weeds were controlled whenever necessary, by manually removing them. No chemical pest or disease control method was necessary.

The arugula and beet, in the two cropping years, were harvested at 30 and 70 day after planting, continuing with evaluations. For the arugula crop, plant height, number of leaves per plant, green mass yield and dry mass of shoots were determined.

For the beet crop we evaluated plant height, number of leaves per plant, productivity of commercial roots, dry mass of shoots, and productivity of classified roots according to diameter, in large $(>7 \mathrm{~cm})$, extra AA $(\geq 6$ and $<7 \mathrm{~cm})$, extra $\mathrm{A}(\geq 5$ and $<6 \mathrm{~cm})$, and extra $(>4$ and $<5 \mathrm{~cm}$ ) (Horta et al., 2001).

In the intercropped system of beet and arugula, the evaluated agronomic and economic indexes were:

a) The system productivity index (SPI), calculated by the expression (Oseni \& Aliyu, 2010): SPI $=\left[\left(\mathrm{Y}_{\mathrm{b}} / \mathrm{Y}_{\mathrm{a}}\right)\right.$ $\left.\mathrm{x}_{\mathrm{ab}}\right]+\mathrm{Y}_{\mathrm{ba}}$, where: $\mathrm{Y}_{\mathrm{b}}$ represents the commercial productivity of beetroots and $\mathrm{Y}_{\mathrm{a}}$ the green mass yield of arugula in single cropping; $Y_{a b}$ is the green mass yield of arugula in intercropped system with beet; $\mathrm{Y}_{\mathrm{ba}}$ is the commercial productivity of beetroots in intercropping with arugula. The advantage of this SPI is that it standardizes the productivity of the secondary crop (arugula) based on the main crop (beet). The higher the value of this index, the more efficient the intercropped system is.

b) The land equivalent coefficient (LEC) determined by the formula used by Diniz et al. (2017): LEC $=\mathrm{LER}_{\mathrm{b}} \mathrm{x}$ $\mathrm{LER}_{\mathrm{a}}$, where: $\mathrm{LER}_{\mathrm{b}}$ and $\mathrm{LER}_{\mathrm{a}}$ represent the partial land equivalent ratios of beet and arugula land, respectively.

Table 1. Description of the population densities of beet and arugula used in the intercropping systems and in the single crops, with their respective spacing. Mossoró, UFERSA, 2018-2019.

\begin{tabular}{lccc}
\hline $\begin{array}{l}\text { Population densities of intercropping } \\
\text { crops (thousand plants ha }\end{array}$ & \multicolumn{2}{c}{ Spacings $(\mathbf{m})$} \\
\hline Beet & Arugula & Beet & Arugula \\
500 & 400 & $0.20 \times 0.05$ & $0.20 \times 0.100(2 \mathrm{pls})^{\dagger}$ \\
500 & 600 & $0.20 \times 0.05$ & $0.20 \times 0.075(2 \mathrm{pls})$ \\
500 & 800 & $0.20 \times 0.05$ & $0.20 \times 0.060(2 \mathrm{pls})$ \\
500 & 1,000 & $0.20 \times 0.05$ & $0.20 \times 0.050(2 \mathrm{pls})$ \\
\hline $\begin{array}{l}\text { Population densities of the crops in } \\
\text { monocropping (thousand plants ha }\end{array}$ & & \\
\hline Beet & 500 & $0.20 \times 0.10$ & \\
Arugula & 1,000 & & $0.20 \times 0.05$ \\
\hline
\end{tabular}

† pls - Means two plants per hole. 
For the intercropped system, the minimum value of LEC is 0.25 ; with that, the intercropped system shows the advantage of production of the index, when it exceeds the value of 0.25 .

c) The monetary equivalent ratio (MER) was determined by the formula used by Afe \& Atanda (2015): MER $=\left(\mathrm{GI}_{\mathrm{ba}}+\mathrm{GI}_{\mathrm{ab}}\right) / \mathrm{GI}_{\mathrm{b}}$, where: $\mathrm{GI}_{\mathrm{ba}}$ is the gross income of beet in intercropping with arugula. $\mathrm{GI}_{\mathrm{ab}}$ is the gross income of arugula in intercropping with beet; $\mathrm{GI}_{\mathrm{b}}$ is the highest gross income of beet in single cropping, compared to the arugula. This index measures the economic superiority, or not, of the intercropping over single cropping of the more economical crop. The higher value of this index, the more viable is the cropping system.

A joint analysis of variance of the two growing years was performed for all variables of the crops in intercropping, using the Sisvar software (Ferreira, 2011), observing the fulfillment of the assumption that the ratio of the mean squares of the errors of the two cropping years, should not be greater than 7 . In the analysis of the agro-economic indices and indicators, homogeneity of variances was observed between the cropping years; so, an average of these indices or indicators between the cropping years was made. After that, a regression analysis was performed for all variables, where a procedure for adjusting a response surface was performed as a function of the equitable amounts of M. aegyptia and C. procera biomass incorporated into the soil and arugula population densities, through the Table Curve 3D software (Systat Software, 2021).

\section{RESULTS AND DISCUSSION}

\section{Arugula crop}

There was no significant interaction between the production factors, equitable amounts of M. aegyptia and C. procera biomass, arugula population densities and cropping years in the evaluated characteristics of the arugula. However, a significant interaction between the cropping years and arugula population densities was recorded only for the plant height (Table 2).
A response surface was adjusted for all characteristics of the arugula as a function of the treatment factors. The maximum values of plant height $(\mathrm{PH})$ obtained in 2018 and 2019 were 15.47 and $17.86 \mathrm{~cm}$ in the arugula densities of 600 and 1,000 thousand plants ha ${ }^{-1}$; the number of leaves per plant (NLP) was 8.5 in the arugula density of 400 thousand plants ha $\mathrm{a}^{-1}$, both characteristics manured in the equitable amount of 65 t ha ${ }^{-1}$ of $M$. aegyptia and C. procera biomass (Figures 1A, 1B and 1C). This higher result in the height of arugula plants in 2019 and in the population density of 1,000 thousand plants $\mathrm{ha}^{-1}$ may be related to the morphological behavior of arugula growth caused by the milder temperatures and higher relative humidity compared to the year 2018. Silva et al. (2021) state that both air temperature and soil temperature affect crop growth and development processes.

In addition, these results show the use of environmental resources by arugula plants, where even in different population densities, the amount of the green manures incorporated into

Table 2. F values for plant height (PH), number of leaves per plant (NLP), green mass yield (GMY) and dry mass of shoots (DMS) of arugula in bi-cropping intercropped with beet in different equitable amounts of $M$. aegyptia and C. procera biomass and population densities of arugula in the cropping years 2018 and 2019. Mossoró, UFERSA, 2018-2019.

\begin{tabular}{|c|c|c|c|c|c|}
\hline Sources of variation & PH & NLP & \multicolumn{2}{|c|}{ GMY } & DMS \\
\hline Blocks (cropping years) & $3.16^{* *}$ & $8.36^{* *}$ & \multicolumn{2}{|c|}{$2.74 * *$} & $4.11 * *$ \\
\hline Cropping years $(\mathrm{Y})$ & $182.46^{* *}$ & $60.11 * *$ & \multicolumn{2}{|c|}{$74.77 * *$} & $11.13 * *$ \\
\hline Amounts of $M$. aegyptia and C. procera biomass (A) & $58.46^{* *}$ & $25.36^{* *}$ & \multicolumn{2}{|c|}{$52.14 * *$} & $21.95 * *$ \\
\hline Population densities of arugula (D) & $2.12^{\mathrm{ns}}$ & $11.26^{* *}$ & \multicolumn{2}{|c|}{$26.66^{* *}$} & $10.95 * *$ \\
\hline Yx A & $1.48^{\mathrm{ns}}$ & $1.09^{\mathrm{ns}}$ & \multicolumn{2}{|c|}{$0.01^{\mathrm{ns}}$} & $0.11^{\mathrm{ns}}$ \\
\hline Y x D & $3.21 *$ & $1.34^{\mathrm{ns}}$ & \multicolumn{2}{|c|}{$0.82^{\text {ns }}$} & $0.54^{\mathrm{ns}}$ \\
\hline$A \times D$ & $1.80^{\mathrm{ns}}$ & $1.08^{\mathrm{ns}}$ & \multicolumn{2}{|c|}{$1.23^{\mathrm{ns}}$} & $0.84^{\mathrm{ns}}$ \\
\hline Y x A x D & $1.14^{\mathrm{ns}}$ & $0.59^{\text {ns }}$ & \multicolumn{2}{|c|}{$0.59^{\mathrm{ns}}$} & $0.84^{\mathrm{ns}}$ \\
\hline Monocropping (M) x Intercropping (I) & $2.21^{\mathrm{ns}}$ & $4.71^{*}$ & \multicolumn{2}{|c|}{$24.51 * *$} & $281.67 * *$ \\
\hline Y x M vs I & $0.04^{\text {ns }}$ & $0.13^{\text {ns }}$ & \multicolumn{2}{|c|}{$20.90 * *$} & $1.27^{\mathrm{ns}}$ \\
\hline $\mathrm{CV}(\%)$ & 7.51 & 9.43 & \multicolumn{2}{|c|}{18.75} & 18.75 \\
\hline \multicolumn{6}{|l|}{ Cropping years } \\
\hline 2018 & 13.40B & $6.90 \mathrm{~B}$ & & & $0.10 \mathrm{~B}$ \\
\hline 2019 & $15.94 \mathrm{~A}$ & $7.84 \mathrm{~A}$ & & & $0.12 \mathrm{~A}$ \\
\hline Cropping systems & & & 2018 & 2019 & \\
\hline Intercropping & $14.08 \mathrm{~A}$ & $7.92 \mathrm{~A}$ & $10.05 \mathrm{aA}$ & $7.93 \mathrm{bA}$ & $0.29 \mathrm{~A}$ \\
\hline Monocropping & $14.67 \mathrm{~A}$ & $7.36 \mathrm{~A}$ & $5.61 \mathrm{bB}$ & $7.76 \mathrm{aA}$ & $0.12 \mathrm{~B}$ \\
\hline
\end{tabular}

$* *=\mathrm{P}<0.01 ; *=\mathrm{P}<0.05 ; \mathrm{ns}=\mathrm{P}>0.05$. $\dagger$ Means followed by different lowercase letters in the row or uppercase in the column differ statistically from each other by the $\mathrm{F}$ test at the $5 \%$ probability level. 
the soil provided sufficient nutrients for a good growth and development of the crop, even though there is a different intraspecific and interspecific competition.

For the green mass yield (GMY) and dry mass of shoots (DMS), the maximum values obtained were 9.65 and $0.16 \mathrm{t} \mathrm{ha}^{-1}$ in the densities of 1,000 and 400 thousand arugula plants $\mathrm{ha}^{-1}$ in the amount of $65 \mathrm{t} \mathrm{ha}^{-1}$ of the green manures biomass (Figures 1D and 1E).
Regardless of the competition provided by the arugula population densities, the amount of $65 \mathrm{t} \mathrm{ha}^{-1}$ of the green manures biomass was responsible for providing a high yield of arugula leaves when intercropped with beet, expressed

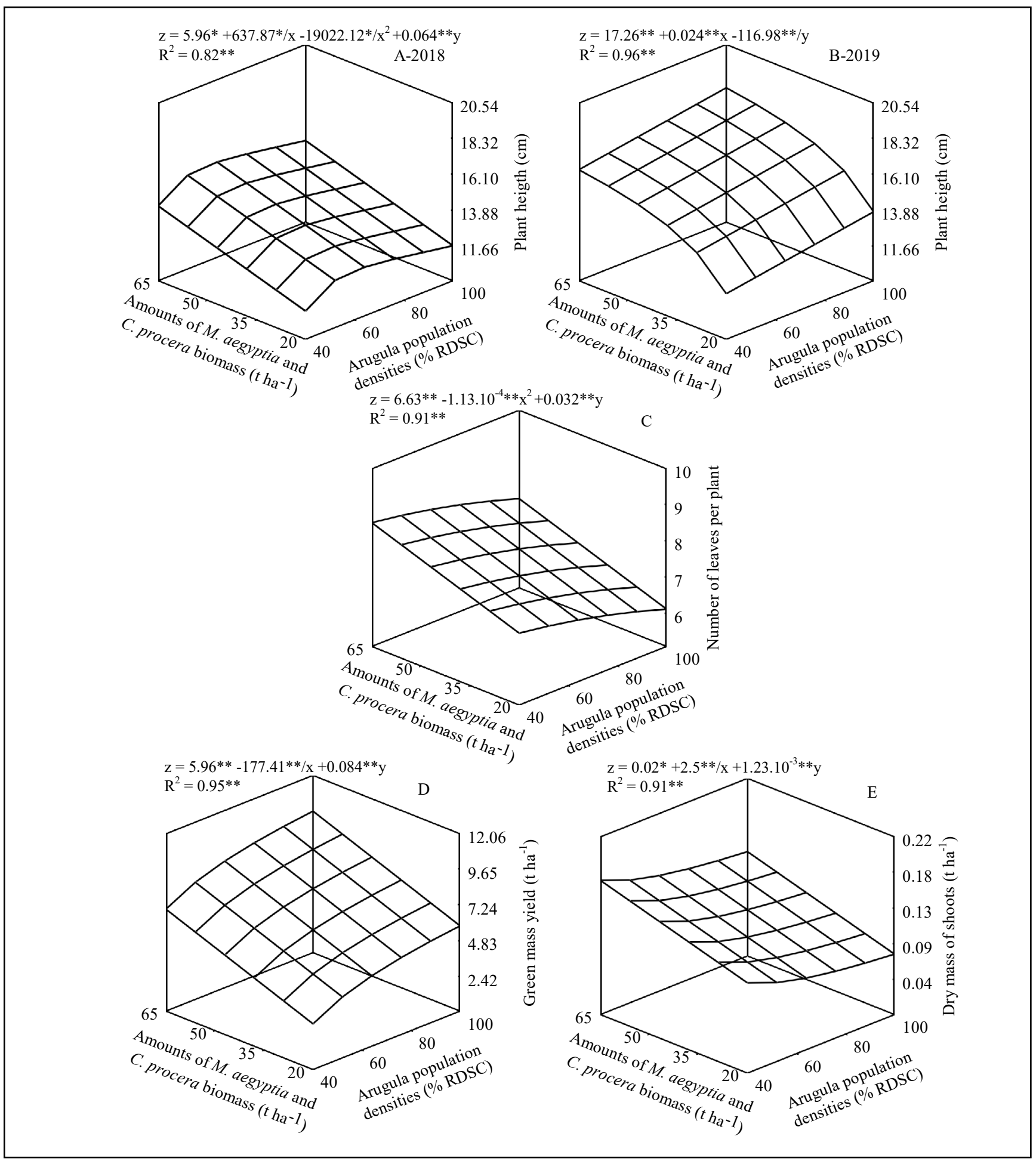

Figure 1. Plant height (A and B), number of leaves per plant (C), green mass yield (D) and dry mass of shoots (E) of arugula in bi-cropping intercropped with beet in different combinations of equitable amounts of $M$. aegyptia and C. procera biomass and arugula population densities in the cropping years 2018 and 2019. Mossoró, UFERSA, 2018-2019. 
in the growth and development of the crop. Filgueira (2013) reports that the efficiency of the use of organic fertilizers is related to the increase in the aerial part and the green mass yield of the plants due to the increase in the availability of nutrients and favoring the physical properties and the activities of the soil organisms.

Significant interaction was recorded between the cropping years and cropping systems only in green mass
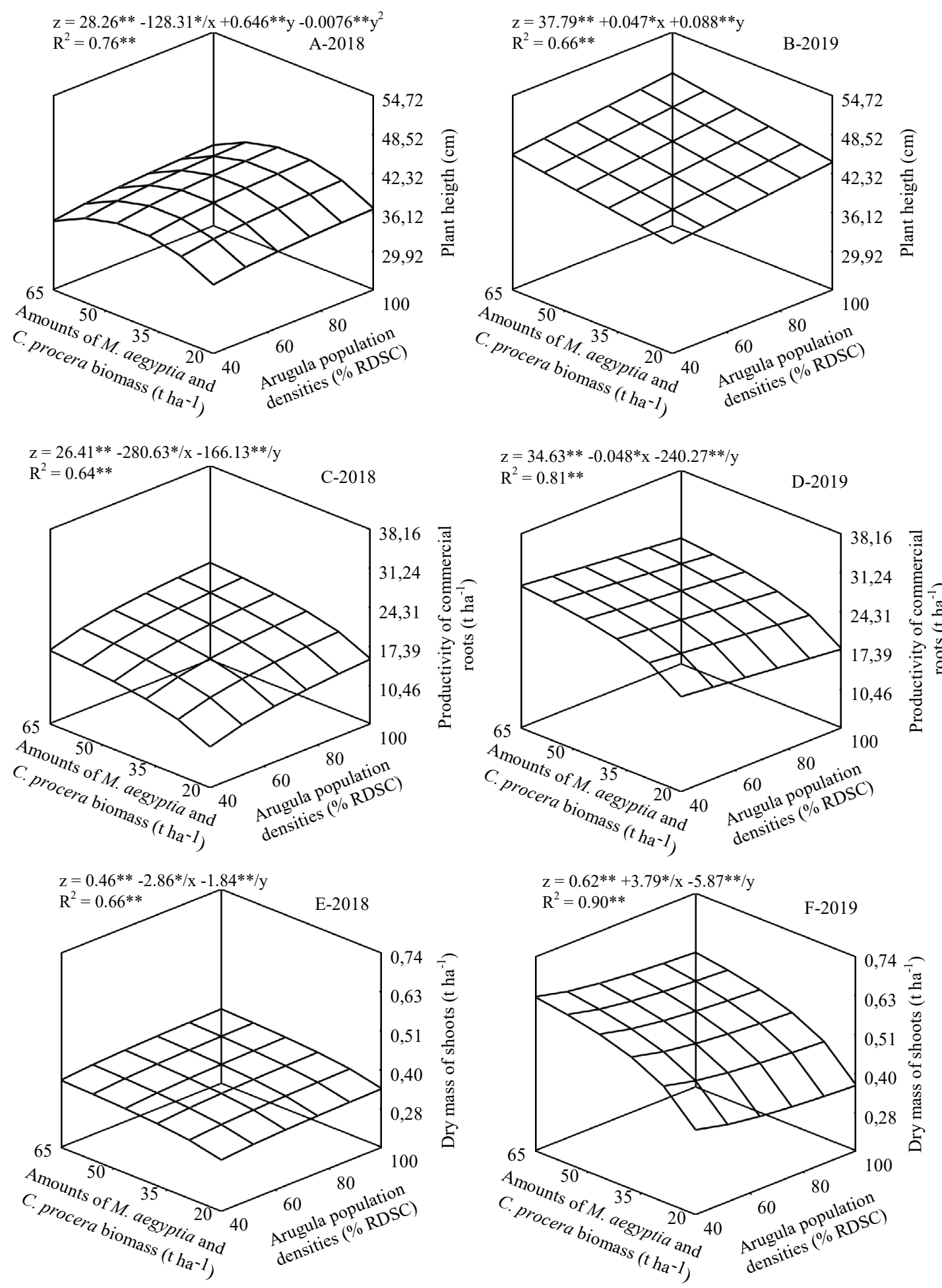

Figure 2. Plant height (A and B), productivity of commercial roots (C and D) and dry mass of shoots (E and F) of beet intercropped with arugula in bi-cropping in different equitable amounts of $M$. aegyptia and $C$. procera biomass and population densities of arugula in the cropping years 2018 and 2019. Mossoró, UFERSA, 2018-2019. 
yield (Table 2). Studying the cropping years within each cropping system, the year 2018 within the intercropped system stood out from 2019 in terms of green mass yield, whereas the yield in 2019 differed from that of 2018 in the monocropping (Table 2). On the other hand, analyzing the cropping systems within each year, in 2018 the arugula green mass yield in the intercropping stood out from that of monocropping, while in 2019 these systems behaved similarly in terms of green mass yield. The climatic differences between 2018 (higher temperatures and lower relative humidity) and 2019 (lower temperatures and higher relative humidity), together with the population densities tested, were the main responsible for these differences in green biomass production of arugula due to intra- and interspecific competition of the intercropped crop in relation to the single crop.

In 2019, the plant height, number of leaves per plant and arugula dry mass of shoots stood out from those of the year 2018. In relation to cropping systems, the intercropping stood out from monocropping in terms of dry mass of arugula shoots. In terms of plant height and number of leaves per plant the cropping systems were similar (Table 2).

Nutritional support and the adequate number of plants per area in intercropped system are essential for good growth and development of crops, thus resulting in productive gains. However, it is known that balanced amounts of nutrients combined with a not too high cultivation density results in an efficient and productive cropping system with products of good commercial quality.

These results obtained from the arugula productivity and its components in the intercropped system indicate that there was maximization in the use of environmental resources, due to improvements in the physical, chemical and biological characteristics of the soil due to the incorporation of the green manures, thus reflecting in greater agronomic efficiency of the intercropped system. It is known that green manuring, in addition to improving soil fertility, increases the organic matter content, decreases erosion rates, favors soil water retention and increases soil microbiota activity, increasing the availability of nutrients and reducing the number of invasive plants (Graham \& Haynes, 2006). On the other hand, morphophysiological differences in crops and treatment factors, such as population density, proportion of crops in intercropping and application of fertilizers, regulate competition between component crops for growth limiting factors (Morgado \& Willey, 2008). Therefore, in view of this, the greater total absorption of nutrients and the increase in the population density of the component crops in the intercropped system were the main cause of obtaining an advantage in the intercropping.

Table 3. F values for plant height (PH), dry mass of shoots (DMS), productivity of commercial roots (PCR) and productivities of large (PLR), extra AA (PEAAR), extra A (PEAR) and extra (PER) roots of beet intercropped with arugula in different equitable amounts of $M$. aegyptia and C. procera biomass and population densities of arugula in the cropping years 2018 and 2019. Mossoró, UFERSA, $2018-2019$.

\begin{tabular}{|c|c|c|c|c|c|c|c|}
\hline Sources of variation & $\mathbf{P H}$ & DMS & PCR & PLR & PEAAR & PEAR & PER \\
\hline $\begin{array}{l}\text { Blocks (cropping } \\
\text { years) }\end{array}$ & $2.19 *$ & $2.30^{*}$ & $2.41 *$ & $0.90^{\mathrm{ns}}$ & $1.09^{\mathrm{ns}}$ & $1.31^{\mathrm{ns}}$ & $0.47^{\mathrm{ns}}$ \\
\hline Cropping years $(\mathrm{Y})$ & $120.74 * *$ & $71.23^{* *}$ & $138.57 * *$ & $194.91 * *$ & $28.24 * *$ & $0.07^{\text {ns }}$ & $23.86^{* *}$ \\
\hline $\begin{array}{l}\text { Amounts of } M . \\
\text { aegyptia and } C . \\
\text { procera biomass (A) }\end{array}$ & $4.52 * *$ & $9.80 * *$ & $35.05 * *$ & $19.86^{* *}$ & $7.21^{* *}$ & $1.22^{\mathrm{ns}}$ & $0.84^{\mathrm{ns}}$ \\
\hline $\begin{array}{l}\text { Population densities } \\
\text { of arugula (D) }\end{array}$ & $3.65^{*}$ & $0.63^{\mathrm{ns}}$ & $1.79^{\text {ns }}$ & $0.23^{\mathrm{ns}}$ & $0.25^{\mathrm{ns}}$ & $2.26^{\mathrm{ns}}$ & $0.90^{\text {ns }}$ \\
\hline Y X A & $5.47 * *$ & $3.70 * *$ & $5.03 * *$ & $5.74 * *$ & $1.49^{\mathrm{ns}}$ & $1.03^{\mathrm{ns}}$ & $4.38^{* *}$ \\
\hline$Y \times D$ & $0.21^{\mathrm{ns}}$ & $1.89^{\text {ns }}$ & $0.41^{\text {ns }}$ & $2.09^{\text {ns }}$ & $0.99^{\text {ns }}$ & $0.11^{\mathrm{ns}}$ & $1.44^{\mathrm{ns}}$ \\
\hline$A \times D$ & $0.38^{\text {ns }}$ & $1.45^{\text {ns }}$ & $0.26^{\text {ns }}$ & $0.68^{\text {ns }}$ & $0.89^{\text {ns }}$ & $0.49^{\text {ns }}$ & $1.50^{\mathrm{ns}}$ \\
\hline Y X A X D & $0.58^{\text {ns }}$ & $0.80^{\text {ns }}$ & $0.89^{\text {ns }}$ & $0.82^{\text {ns }}$ & $0.52^{\text {ns }}$ & $0.58^{\text {ns }}$ & $1.00^{\mathrm{ns}}$ \\
\hline $\begin{array}{l}\text { Monocropping (M) } \mathrm{x} \\
\text { Intercropping (I) }\end{array}$ & $8.10 * *$ & $1.24^{\mathrm{ns}}$ & $43.43 * *$ & $3.33^{*}$ & $9.27 * *$ & $7.75^{* *}$ & $6.43 *$ \\
\hline Y x M vs I & $8.98 * *$ & $1.88^{\mathrm{ns}}$ & $23.12 * *$ & $0.06^{\mathrm{ns}}$ & $0.93^{\mathrm{ns}}$ & $11.61 * *$ & $14.16^{* *}$ \\
\hline CV $(\%)$ & 8.90 & 23.35 & 14.93 & 45.87 & 35.20 & 39.25 & 28.53 \\
\hline \multicolumn{8}{|l|}{ Cropping years } \\
\hline 2018 & $37.77 \mathrm{~B}$ & $0.36 \mathrm{~B}$ & $17.17 \mathrm{~B}$ & $3.62 \mathrm{~B}$ & $4.97 \mathrm{~B}$ & $4.20 \mathrm{~A}$ & $4.38 \mathrm{~A}$ \\
\hline 2019 & $46.80 \mathrm{~A}$ & $0.52 \mathrm{~A}$ & $24.43 \mathrm{~A}$ & $10.08 \mathrm{~A}$ & $7.02 \mathrm{~A}$ & $4.03 \mathrm{~A}$ & $3.30 \mathrm{~B}$ \\
\hline Cropping systems & $2018 \quad 2019$ & & $2018 \quad 2019$ & & & $2018 \quad 2019$ & \begin{tabular}{|ll}
2018 & 2019 \\
\end{tabular} \\
\hline Intercropping & $37.77 \mathrm{bB} 44.80 \mathrm{aA}$ & $0.44 \mathrm{~A}$ & $17.33 \mathrm{bB} 26.24 \mathrm{aA}$ & $5.16 \mathrm{~B}$ & $5.99 \mathrm{~B}$ & $4.20 \mathrm{aA} \quad 4.03 \mathrm{aB}$ & $4.38 \mathrm{aA} 3.30 \mathrm{bA}$ \\
\hline Monocropping & $45.21 \mathrm{aA} 44.61 \mathrm{bA}$ & $0.48 \mathrm{~A}$ & $32.79 \mathrm{aA} \quad 25.94 \mathrm{bA}$ & $7.28 \mathrm{~A}$ & $8.39 \mathrm{~A}$ & $3.82 \mathrm{bA} \quad 7.76 \mathrm{aA}$ & $1.90 \mathrm{bB} 3.78 \mathrm{aA}$ \\
\hline
\end{tabular}

$* *=\mathrm{P}<0.01 ; *=\mathrm{P}<0.05 ; \mathrm{ns}=\mathrm{P}>0.05{ }^{\dagger}$ Means followed by different lowercase letters in the row or uppercase in the column differ statistically from each other by the $\mathrm{F}$ test at the $5 \%$ probability level. 
Oliveira et al. (2015b), working with the agronomic viability of arugula and lettuce bi-cropping in intercropping with carrot in strip- intercropping under different amounts of $C$. procera biomass in different population densities, reported a low interspecific competition between crops, since the best productive performances of intercropped systems were observed in the highest population densities, due to the better use of environmental
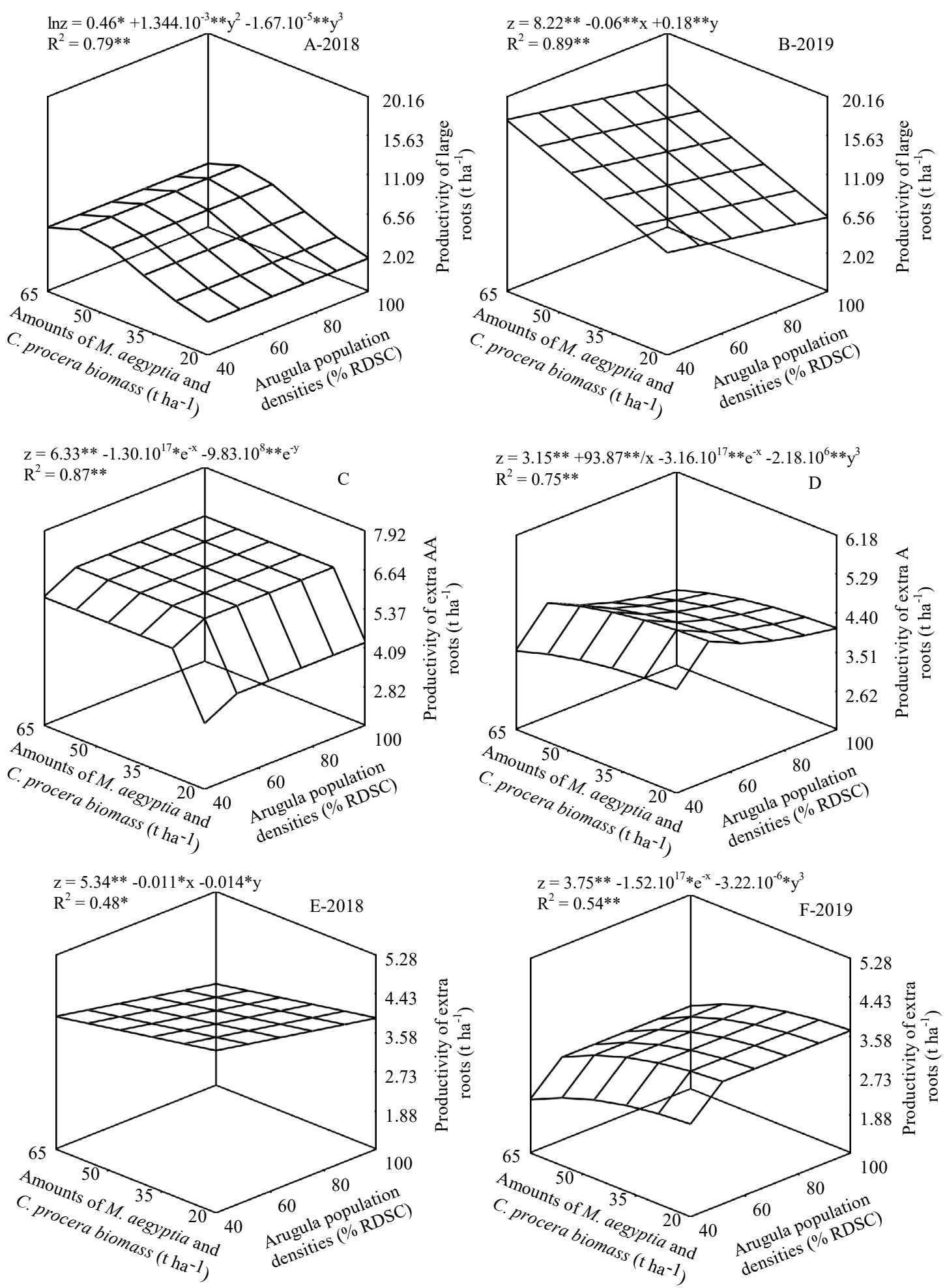

Figure 3. Productivity of large (A and B), extra AA (C), extra A (D) and extra (E and F) beetroots intercropped with arugula in bi-cropping in different equitable amounts of $M$. aegyptia and $C$. procera biomass and population densities of arugula in the cropping years 2018 and 2019. Mossoró, UFERSA, 2018-2019. 
resources by the component crops.

\section{Beet crop}

There was no significant interaction between production factors, biomass equitable amounts of $M$. aegyptia and C. procera, arugula population densities and cropping years in the evaluated characteristics of beet. However, significant interactions between cropping years and equitable amounts of $M$. aegyptia and $C$. procera biomass were recorded only for the agronomic variables: plant height, shoot dry matter, productivity of commercial roots, and productivities of large and extra roots (Table 3).

A response surface was adjusted for each interaction, where the maximum values reached in these agronomic variables were, respectively, 40.68 and $48.23 \mathrm{~cm}(\mathrm{PH}) ; 21.04$ and $29.01 \mathrm{t} \mathrm{ha}^{-1}$ (PCR); 0.41 and 0.62 tha $^{-1}$ (DMS); 4.27 and $16.69 \mathrm{t} \mathrm{ha}^{-1}$ (PLR) and 4.60 and $3.73 \mathrm{tha}^{-1}$ (PER) in the combinations of equitable amounts of $M$. aegyptia and $C$. procera biomass and arugula population density of 42 and 1,000 thousand and 65 and 1,000 thousand; 65 and 1,000 thousand and 65 and 400 thousand; 65 and 1,000 thousand and 65 and 400 thousand; 65 and 1,000 thousand and 65 and 400 thousand; 20 and 400 thousand and $20 \mathrm{t} \mathrm{ha}^{-1}$ and 900 thousand plants ha $^{-1}$ in the cropping years 2018 and 2019 (Figures 2A, 2B, 2C, 2D, 2E, 2F, 3A, $3 \mathrm{~B}, 3 \mathrm{E}$ and $3 \mathrm{~F})$. The climatic differences between 2018 (higher temperatures and lower relative humidity) and 2019 (lower temperatures and higher relative humidity), together with the population densities tested, were the main responsibles for these differences in the evaluated characteristics.

In view of these results, it can be clearly seen that the best combination between the biomass amounts of the mixtures of the green manures and the arugula population densities in the cropping years, was registered in the biomass amount of $65 \mathrm{t} \mathrm{ha}^{-1}$ of $M$. aegyptia and $C$. procera independently of the population density used in agronomic variables: plant height, commercial productivity, dry mass of shoots and productivity of large roots. These results are related to the nutritional contribution, due to the efficiency of the highest dose of green manures, which promoted the good development of the crops. However, it is known that the adequate supply of nutrients incorporated into the soil, can promote the good growth and vegetative development of the crops, the expansion of the photosynthetic area and the activation and increase of the production potential (Favacho et al., 2017).

The results obtained from the height of beet plants may also be associated with the intense competition for light, due to the increase in the population density of the arugula, which probably promoted the growth of the beet. With less space between component crops of the intercropping, beet plants grew in search of light, the main climatic element that determines their growth, in addition to the water and nutrients available in the soil solution, as reported by Taiz \& Zeiger (2013).

For the dry mass of beet shoots in 2019 , it can be inferred that the greater shading imposed by the increase in the number of arugula plants in the area, negatively impacted photosynthesis and, consequently, allowed the dry mass of beet shoots reach the maximum in a lowest population. Shading reduces

Table 4. F values for system productivity index (SPI), land equivalent coefficient (LEC) and monetary equivalent ratio (MER) of beet intercropped with arugula in different equitable amounts of M. aegyptia and C. procera biomass and population densities of arugula. Mossoró, UFERSA, 2018-2019.

\begin{tabular}{lccc}
\hline Sources of variation & SPI & LEC & MER \\
\hline Blocks & $0.45^{\mathrm{ns}}$ & $1.33^{\mathrm{ns}}$ & $0.81^{\mathrm{ns}}$ \\
Amounts of M. aegyptia and C. procera biomass (A) & $21.47^{* *}$ & $14.33^{* *}$ & $16.02^{* *}$ \\
Population densities of arugula (D) & $84.72^{* *}$ & $77.60^{* *}$ & $90.66^{* *}$ \\
A x D & $1.23^{\mathrm{ns}}$ & $1.41^{\mathrm{ns}}$ & $1.32^{\mathrm{ns}}$ \\
\hline CV $(\%)$ & 10.67 & 15.70 & 7.92 \\
\hline
\end{tabular}

$* *=\mathrm{P}<0.01 ; \mathrm{ns}=\mathrm{P}>0.05$. the production of dry mass, as it causes a deficiency in the translocation of photoassimilates, as reported by Paciullo et al. (2011). Therefore, the maximum dry mass production of the beet was achieved in the lowest arugula density tested. In intercropped systems, where the nutritional conditions of the soil are suitable for cultivation, competition for light can be more intense, and the use of higher densities can increase competition for this natural resource (Gebru, 2015; Nascimento et al., 2018).

The increase in productivity with the equitable amounts of the green manures is due, in part, to the greater availability of nutrients, mainly N, P and $\mathrm{K}$ released by fertilizers (Batista et al., 2016), as well as by the improvement in the chemical and physico-chemical characteristics of the soil obtained by adding these increasing amounts of green manures. According to Fontanétti et al. (2006), the absorption of nutrients resulting from the mineralization of these green manures by vegetables depends, to a large extent, on the synchrony between the decomposition and mineralization of plant residues and of the moment of greatest demand for the crop.

A response surface was adjusted for the productivities of extra AA and extra A roots, where the maximum values obtained in these variables were 6.33 and $5.25 \mathrm{t} \mathrm{ha}^{-1}$ in the combinations of green manures biomass amounts and arugula population densities of $65 \mathrm{t}$ $\mathrm{ha}^{-1}$ and 830 thousand, and $20 \mathrm{tha}^{-1}$ and 430 thousand plants ha $^{-1}$, respectively (Figures 3C and 3D). This increase in productivity is also due to the increase in population density up to a certain density, where there is a decrease in those productivities (extra AA and extra A roots), due to the excessive competition that is established between the crop plants of the cultivation system.

There were significant interactions between crop systems and cropping years for the agronomic characteristics evaluated in the beet except for the dry mass of shoots, productivity of large roots and productivity of extra AA roots (Table 3). Studying the cropping years within the intercropping, 2019 stood out from 2018 in terms of plant height and commercial productivity, while 
in the case of extra root productivity the behavior was reverse. This result is possibly related to the sharing of environmental resources by the intercropping system in the year where the weather conditions were not the most favorable, consequently producing smaller sized roots of beetroot, as extra sized roots. No differences were observed between the cropping years in the productivity of extra A roots. On the other hand, within the monocropping, the year 2018 differed from 2019 in plant height, commercial productivity, while in the productivities of roots extra $\mathrm{A}$, and extra the behavior was reverse (Table 3).

Studying the cropping systems within cropping years, it can be seen that within the year 2019, the intercropped system did not differ from the monocropping in the plant's height, in the commercial productivity and in the productivity of extra beetroots; however, the productivity of extra A roots, was surpassed by monoculture (Table 3 ). In 2018 , monocropping stood out from the intercropping in terms of plant height and commercial root productivity, while in the case of productivity of extra roots, the behavior was reverse. There was no significant difference between cropping systems in the productivity of extra A roots in that year.

In the productivity of large and extra AA roots, the monocropping stood out from the intercropping; however, in the dry mass of shoots there was no significant difference between the cropping systems (Table 3 ).

The increase in productivity with the addition of the green manures must be evidenced by the nutritional complementarity provided by the mixture of the two species through the cycling of nutrients (Favacho et al., 2017). The highest productivity of large roots was achieved by combining the highest amount of biomass mixture of green manures, with the highest arugula population density tested in 2018 , and with the lowest arugula density in 2019. This shows that the interspecific competition was not affected by population density, thus allowing the highest productivity of large roots to be achieved in the greatest amount of the green manures incorporated. This result was due to the climatic differences between 2018 (higher temperatures and lower relative humidity) and 2019 (lower temperatures and higher relative humidity).

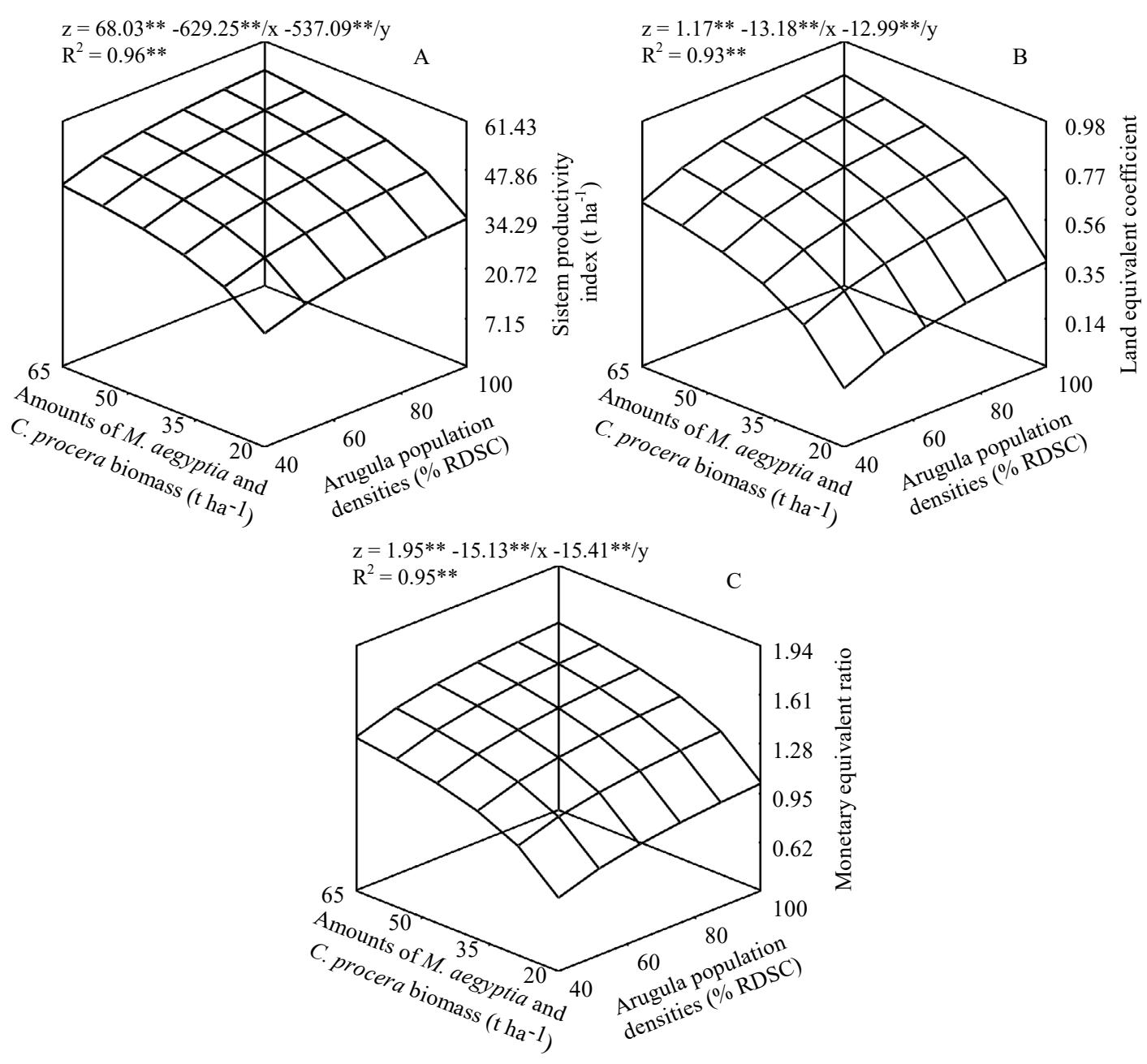

Figure 4. System productivity index (A), land equivalent coefficient (B) and monetary equivalent ratio (C) of beet intercropped with arugula in bi-cropping in different equitable amounts of $M$. aegyptia and C. procera biomass and population densities of arugula. Mossoró, UFERSA, 2018-2019. 


\section{Agro-economic indexes}

Significant interactions between the factors of production studied, equitable amounts of $M$. aegyptia and $C$. procera biomass and population densities of arugula were recorded for the agroeconomic indices: system productivity index (SPI), land equivalent coefficient (LEC), and monetary equivalent ratio (MER) (Table 4).

However, a response surface was adjusted for each agro-economic index (Figure 4). The maximum values reached for SPI, LEC and MER were $53.47 \mathrm{t} \mathrm{ha}^{-1}, 0.84$ and 1.56 in the combination of equitable amount of the green manures biomass and arugula population densities of $65 \mathrm{t} \mathrm{ha}^{-1}$ and 1,000 thousand plants ha ${ }^{-1}$, respectively (Figures 4A, 4B and 4C).

These results also indicate that the use of high population densities of the arugula crop (secondary crop), did not result in a negative effect on the system intercropped with beet, mainly in terms of competitive pressure by solar radiation, nutrients and other environmental resources. It is known that the population of plants in intercropped systems depends on the type and growth habit of crops, soil fertility, precipitation and other growth requirements (Balasubramaniyan \& Palaniappan, 2001). In the case under study, the architecture and morphology of the beet and arugula crops are completely different with regard to the demand for environmental resources, as they demand in different times and occupied spaces.

Thus, these agro-economic indices obtained due to the equitable amounts of $M$. aegyptia and $C$. procera biomass, were partly due to the good nutritional support provided by the mixture of green manures, which were able to efficiently meet the needs of crops, so they expressed their productive potential in a situation of high density. It is known that green manures from biomass of regional plants or not, increase not only the organic matter and the level of nutrients in the soil, but improve the structure, aeration and water storage capacity in the soil, thus contributing to the chemical, physical and biological properties of the soil (Silva et al., 2020). According to Tivelli et al. (2010), green manures can also provide nutrient cycling in the soil, bringing nutrients that are in greater depth to the surface.

The high SPI value (53.47 $\mathrm{t} \mathrm{ha}^{-1}$ ) obtained in the combination of $65 \mathrm{tha}^{-1}$ of the mixture of the green manures with 1,000 thousand arugula plants ha-1 demonstrates the agronomic efficiency of the intercropped system of beet with arugula in this combination in relation to the monocropping system of these cultures. Likewise, the high LEC value obtained (0.84), expressed this same agronomic efficiency of the intercropping of these two vegetables in this same combination of treatment factors. According to Diniz et al. (2017), when the LEC value is greater than 0.25 the intercropped system shows an advantage of production in relation to monocropping of the cultures.

In addition, it is possible to observe by the obtained value of MER (1.56) that the agronomic efficiency of the beet and arugula intercropping was translated into economic terms by MER. When MER is greater than 1.0, the intercropped systems are considered more profitable in relation to monocroppings (Afe \& Atanda, 2015). This superiority of MER can be attributed to the complementary nature of the cultures involved.

The obtained results corroborate those obtained by Guerra et al. (2021), who intercropped beet with different population densities of lettuce, in the same region of this research, and obtained values of SPI $=32.75 \mathrm{t} \mathrm{ha}^{-1}$, $\mathrm{LEC}=0.75$ and $\mathrm{MER}=1.55$, in the combination of equitable amounts of green manures biomass of $65 \mathrm{tha}^{-1}$ with a population density of 300 thousand plants of lettuce per hectare.

Therefore, we can infer that the technology of the mixture of $M$. aegyptia and $C$. procera from the Caatinga biome is viable for the production of beet and arugula in an intercropped system in the semi-arid region. Thus, with appropriate designs of intercropped systems of tuberous vegetables with leafy vegetables, producers can obtain high system production and optimize the yields of component crops by planted area, in addition to carrying out beneficial management in all aspects for the soil and environment as well as obtaining high economic profitability of the intercropped systems.

The maximum optimized commercial production of beetroots in the intercropped system with arugula was $23.20 \mathrm{t} \mathrm{ha}^{-1}$ using $65 \mathrm{t} \mathrm{ha}^{-1}$ of $M$. aegyptia and $C$. procera biomass in a density of 1,000 thousand arugula plants ha $^{-1}$. Maximum productivity of arugula intercropped with beet was 9.65 $\mathrm{t} \mathrm{ha}^{-1}$, in the same combination of green manures amount and population density of arugula. The maximum optimized productivities for large roots, extra AA and extra were $10.28 ; 6.33$ and $4.12 \mathrm{t} \mathrm{ha}^{-1}$ obtained using $65 \mathrm{t} \mathrm{ha}^{-1}$ green manure biomass and in the arugula population densities of 850; 820 and 400 thousands plants ha ${ }^{-1}$, respectively.

\section{REFERENCES}

AFE, AI; ATANDA, S. 2015. Percentage yield difference, an index for evaluating intercropping efficiency. American Journal of Experimental Agriculture 5: 459-465.

ALVARES, CA; STAPE, JL; SENTELHA, PC; GONÇALVES, JLM; SPAROVEK, G. 2014. Köppen's climate classification map for Brazil. Meteorologische Zeitschrift 22: 711-728.

ANDRADE FILHO, FC; OLIVEIRA, EQ; LIMA, JSS; MOREIRA, JN; SILVA, IN; LINS, HA; CECÍLIO FILHO, AB; BARROS JUNIOR, AP; BEZERRA NETO, F. 2020. Agro-economic viability from two croppings of broadleaf vegetables intercropped with beet fertilized with roostertree in different population densities. Revista de la Facultad de Ciencias Agrarias 52: 210-224.

BALASUBRAMANIYAN, P; PALANIAPPAN, SP. 2001. Principles and practices of agronomy. Jodhpur, India: Agrobios. p. 486-499.

BATISTA, TMV; BEZERRA NETO, F; PORTO, VCN; BARROS JÚNIOR, AP; SILVA, IN; SILVA, ML; LIMA, JSS; OLIVEIRA, EQ. 2016. Bio-agroeconomic returns from carrot and salad rocket as intercrops using hairy woodrose as green manure in a semi-arid region of Brazil. Ecological Indicators 67: 458-465.

BEZERRA NETO, F; BARROS JÚNIOR, AP; NEGREIROS, MZ; OLIVEIRA, EQ; SILVEIRA, LM; CÂMARA, MJT. 2005. Associação de densidades populacionais de cenoura e alface no desempenho agronômico da cenoura em cultivo consorciado em faixa. Horticultura Brasileira 23: 233-237.

DINIZ, WJS; SILVA, TGF; FERREIRA, JMS; SANTOS, DC; MOURA, MSB; ARAÚJO, GGL; ZOLNIER, S. 2017. Forage cactussorghum intercropping at different irrigation water depths in the Brazilian semiarid region. Pesquisa Agropecuária Brasileira 52: 724 733.

FAVACHO, FS; LIMA, JSS; BEZERRA NETO, 
F; SILVA, JN; BARROS JÚNIOR, AP. 2017. Eficiência produtiva e econômica do consórcio de cenoura $\mathrm{x}$ caupi proveniente de adubação verde e arranjos espaciais. Revista Ciência. Agronômica 48: 337-346.

FERREIRA, DF. 2011. Sisvar: a computer statistical analysis system. Ciência e Agrotecnologia 35: 1039-1042.

FILGUEIRA, FAR. 2013. Novo manual de olericultura: agrotecnologia moderna na produção e comercialização de hortaliças. 3 . ed. Revisada e Ampliada. Viçosa: UFV, 421 p.

FONTANÉTTI, A; CARVALHO, GJ; GOMES, LAA; ALMEIDA, K; MORAES, SRG; TEIXEIRA, C M. 2006. Adubação verde na produção orgânica de alface americana e repolho. Horticultura Brasileira 24: 146-150.

GEBRU, H. 2015. A review on the comparative advantages of intercropping to mono-cropping system. Journal of Biology, Agriculture and Healthcare 5: 1-13.

GRAHAM, MH; HAYNES, RJ. 2006. Organic matter status and the size, activity and metabolic diversity of the soil microbial community in the row and inter-row of sugar cane under burning a trash retention. Soil Biology \& Biochemistry 38: 21-31.

GUERRA, NM; BEZERRA NETO, F; LIMA, JSS; SANTOS, EC; NUNES, RLC; PORTO, VCN; QUEIROGA, RCF; LINO, VAS; SÁ, JM. 2021. Productive and agro-economic benefits in beet-lettuce intercropping under organic manuring and population densities. Research, Society and Development 10: 1-25.

HORTA, ACS; SANTOS, HS; SCAPIM, CA; CALLEGARI, O. 2001. Relação entre produção de beterraba, Beta vulgaris var. conditiva, e diferentes métodos de plantio. Acta Scientiarum 23: 1123-1129.

INMET - Instituto Nacional de Meteorologia. 2019. Dados meteorológicos. Brasilia: Ministério da Agricultura, Pecuária e Abastecimento. Available at https://portal.inmet.gov.br.

LINHARES, PCF; PEREIRA, MFS; ASSIS, JP; BEZERRA, AKH. 2012. Amounts and times of decomposition of scarlet starglory on agronomic performance of cilantro. Ciência Rural 42: 243-248.

MORGADO, LB; WILLEY, RW. 2008. Optimum plant population for maize-bean intercropping system in the Brazilian semi-arid region. Scientia Agricola 65: 474-480.

MORAES, EC; LIMA, JSS; BEZERRANETO, F; LINHARES, PCA; COSTA, AP; CRISPIM, JF; ANDRADE, LIF; RODRIGUES, GSO. 2019. Effects of different roostertree (Calotropis procera) amounts and spatial arrangements on the performance of the beet-cowpea intercropping system. Australian Journal of Crop Science 13: 486-493.

NASCIMENTO, CS; CECÍLIO FILHO, AB; CORTEZ, JWM; NASCIMENTO, CS; BEZERRA NETO, F; GRANGEIRO, LC. 2018. Effect of population density of lettuce intercropped with rocket on productivity and land-use efficiency. Plos One 13: 1-14.

OLIVEIRA, KJB; LIMA, JSS; SOARES APS; BEZERRA NETO, F; LINHARES, PCA. 2015a. Produção agroeconômica da rúcula fertilizada com diferentes quantidades de Calotropis procera. Terceiro Incluido 5: 373-384.

OLIVEIRA, LAA; BEZERRA NETO, F; SILVA, ML; OLIVEIRA, OFN; LIMA, JSS; BARROS JÚNIOR, AP. 2015b. Viabilidade agronômica de policultivos de rúcula/cenoura/alface sob quantidades de flor-de-seda e densidades populacionais. Revista Caatinga 28: 116-126.

OLIVEIRA, LJ; BEZERRA NETO, F; LIMA, JSS; OLIVEIRA, EQ; MOREIRA, JN; SILVA, IN. 2017. Viability of polycultures of arugula-carrot-coriander fertilized with hairy woodrose under different population densities. Revista Brasileira de Engenharia Agrícola e Ambiental 21: 611-617.

OLIVEIRA NETO, DH; CARVALHO, DF; SILVA, LDB; GUERRA, JGM; CEDDIA, MB. 2011. Evapotranspiração e coeficientes de cultivo da beterraba orgânica sob cobertura morta de leguminosa e gramínea. Horticultura Brasileira 29: 330-334.

OSENI, TO; ALIYU, IG. 2010. Effect of row arrangements on sorghum-cowpea intercrops in the semi-arid savannah of Nigeria. International Journal of Agriculture and Biology 12: 137-140.

PACIULLO, DSC; GOMIDE, AM; CASTRO, CRT; FERNANDES, PB; MÜLLER,
MD; PIRES, MFA; FERNANDES, EN; XAVIER, DF. 2011. Características produtivas e nutricionais do pasto em sistemas agrossilvipastoril, conforme a distância das árvores. Pesquisa Agropecuária Brasileira 46: 1176-1183.

SANTOS, HG; JACOMINE, PKT; ANJOS, LHC; OLIVEIRA, VÁ; LUMBRERAS, JF; COELHO, MR; ALMEIDA, JA; ARAÚJO FILHO, JC; OLIVEIRA, JB; CUNHA, TJF. 2018. Sistema brasileiro de classificação de solos. 5. ed. rev. e ampl. Brasília: Embrapa. $356 \mathrm{p}$.

SILVA, MG; SHARMA, RD; JUNQUEIRA, AMR; OLIVEIRA, CM. 2006. Efeito da solarização, adubação química e orgânica no controle de nematoides em alface sob cultivo protegido. Horticultura Brasileira 24: 489-494.

SILVA, ML; BEZERRA NETO, F; LINHARES, PCF; SÁ, JR; LIMA, JSS; BARROS JÚNIOR, AP. 2011. Produção de beterraba fertilizada com jitirana em diferentes doses e tempos de incorporação ao solo. Revista Brasileira de Engenharia Agrícola e Ambiental 15: 801-809.

SILVA, IN; BEZERRA NETO, F; BARROS JÚNIOR, AP; LIMA, JSS; BATISTA, TMV; LINS, H. A. 2018. Green manure and spatial arrangement in the sustainability improvement of lettuce-beet intercrops. Revista Brasileira de Engenharia Agrícola e Ambiental 22: 451-457.

SILVA, JN; BEZERRA NETO, F; LIMA, JSS; SANTOS, EC; NUNES, RLC; CHAVES, AP. 2020. Production and benefits in carrot and vegetable cowpea associations under green manuring and spatial arrangements. Revista Ciência. Agronômica 51: 1-11.

SILVA, TRG; COSTA, MLA; FARIAS, LRA; SANTOS, MA; ROCHA, JJL; SILVA, JV. 2021. Fatores abióticos no crescimento e florescimento das plantas. Research, Society and Development 10: 1-9.

SYSTAT SOFTWARE INC. 2021. Table curve $3 D$ Academic Edition. San Jose, CA: Systat Software Inc.

TAIZ, L; ZEIGER, E. 2013. Fisiologia vegetal. 4. ed. Porto Alegre: Artmed, p. 819.

TIVELLI, SW; PURQUEIRO, LFV; KANO, C. 2010. Adubação verde e plantio direto em hortaliças. Pesquisa \& Tecnologia 7: 1-7. 